\title{
CHARACTERISTICS OF BLOOMING AND POLLEN IN FLOWERS OF TWO Syringa SPECIES (f. Oleaceae)
}

\author{
Bożena Denisow, Monika Strzałkowska-Abramek \\ Department of Botany, Laboratory of Horticultural Plant Biology, University of Life Sciences in Lublin \\ Akademicka 15, 20-950 Lublin, Poland \\ e-mail: bozena.denisow@up.lublin.pl
}

Received: 12.06.2013

\begin{abstract}
The observations were conducted in long-term sequence studies in the years 2006, 2009, 2013, in the Lublin area, Poland ( $\left.51^{\circ} 16^{\prime} \mathrm{N}, 22^{\circ} 30^{\prime} \mathrm{E}\right)$. The flowering phenology, diurnal pattern of blooming, pollen production and insect visitation to the shrubs of Syringa oblata Lindl. var. dilatata (Nakai) Rehd. and S. meyeri 'Palibin' Schn. were examined.

Syringa oblata var. dilatata and S. meyeri 'Palibin' bloomed from the mid May till mid June. The species are characteristic of early morning diurnal pattern of blooming, with approx. of $60 \%$ of daily instalment of flowers opened before 9.00 (GMT $+2 \mathrm{~h}$ ). Both species studied had the corolla tube 2-fold deeper during the pollen shedding phase compared to bud stage (mean $=14.9 \mathrm{~mm} \pm 3.2 \mathrm{SD}$ vs. $7.8 \mathrm{~mm} \pm 2.8$ ). No species effect was found for the size of anthers, for the mass of pollen produced in anthers and for the pollen viability. A constant number of 2 stamens in the flowers of Syringa species entailed the pollen yield was derivative mainly to the number of developed flowers. Therefore significant differences were noted for the pollen yield between individual shrubs (mean $0.9 \mathrm{~kg}$ for $S$. meyeri 'Palibin', and $8.1 \mathrm{~kg} / \mathrm{ha}$ for $S$. oblata var. dilatata).

The Syringa oblata var. dilatata and S. meyeri 'Palibin' due to their attractive flowering period, and the abundance of blooming are suitable for different ornamental designs in urban areas. Unfortunately, despite the entomophilous flower traits, the insect visitors appeared sporadically.
\end{abstract}

Key words: Syringa oblata var. dilatata, S. meyeri 'Palibin', phenology, abundance of blooming, mass of pollen

\section{INTRODUCTION}

The genus Syringa L., lilacs, includes about 30 species, of woody, multi-stemmed shrub plants in the family Oleaceae [1]. The species are native to the mountain areas of south-eastern Europe and eastern
Asia and within the range of their origin are considered as insect pollinated [2]. Lilacs, due to delicious fragrant and abundant blooming, are one of the most widely cultivated ornamental trees and shrubs in temperate regions of the world [3]. Several hundred cultivars have been developed through extensive hybridization and artificial selection [4]. The plants (e.g. Syringa vulgaris) have been used ethnobotanically to reduce fever and treat malaria, as a perfume and a tonic, and in homeopathy [5].

The flowers are tiny, from the basic single, and semi-double to double. The genus Syringa is divided into two subgenera, and one of these Ligustrina L. has flowers with corolla tube shorter than corolla lobs. The second subgenus Syringa L. has generally corolla tube longer then calyx [6]. The single flowers of Syringa species are reported to be visited by hummingbirds, bees and butterflies [7]. In the former Soviet Union, the $S$. vulgaris was mentioned as nectariferous [8]. In Poland $S$. reticulata is regarded as melliferous plant $[9,10]$ and is attractive for bees [7]. The pollen grains of the Syringa type are noted in bee products $[11,12]$.

In Poland different ornamental species are recognised as a source of nectar for insect visitors [13-15]. The species from the genus Syringa are very popular in different garden designs mainly in urban areas $[6,16]$, it means reasonable, when a native knowledge is not yet available, to fulfil the gape in the aspects of lilack's blooming biology.

The main objective of the study was to 1) examine floral phenology and diurnal dynamics of flowering for two ornamental shrubs species Syringa oblata var. dilatata and $S$. meyeri 'Palibin' 2) estimate the quantity of pollen, and 3) to monitor the activity and spectrum of insect visitors. 


\section{MATERIALS AND METHODS}

Study sites and study species. The observations were conducted in long-term sequence studies in 2006, 2009,2013 , in the Lublin area, Poland $\left(51^{\circ} 16^{\prime} \mathrm{N}, 22^{\circ}\right.$ 30 ' E). The shrubs of Syringa oblata Lindl. var. dilatata (Nakai) Rehd. and S. meyeri 'Palibin' Schn. were grown at the arboretum section in the Botanical Garden Maria Curie-Skłodowska University. The species are known as frost resistant, they are decorative both in blooming and autumn leaf colour change phases, and are recommended as ornamentals. The experimental individuals shrubs were grown on a loess originated soil. Standard plant protection treatments were applied, when necessary.

Flowering observations. During the growing seasons detailed observations of flowering biology were conducted. The onset and length of blooming period was recorded. The observations of the diurnal model of blooming were made in 2006 and 2009. Protocols described by Jabłoński and Szklanowska [17] and D e $n$ is ow [18] were applied.

The diurnal pattern of flowering was expressed as the percentage of newly opened flowers in relation to the total number of flowers opened during the day. The development of flowers was noted in one-hour intervals, between 8.00 and $20.00 \mathrm{~h}(\mathrm{GMT}+2 \mathrm{~h})$. To determine flower life-span, the buds ( $\mathrm{n}=10$ per each cultivar) were randomly chosen on different individual shrubs. The buds were marked just before opening and their development was observed. The flower life-span was defined as the period from bud-opening till the corolla withering. As the weather conditions were changeable during flowering periods the impact of air temperature on the flower longevity was assessed.

The average number of flowers produced per each individual shrub was established. The abundance of blooming was determined on the basis of the number of flowers per inflorescence $(n=30)$, the number of inflorescences per shoot $(n=15)$, and the number of shoots per shrub.

Pollen production was determined for the full blooming phase assayed using the standard method described in details by D e $\mathrm{n}$ i s o w [19]. The fresh and dry mass of anthers with pollen was determined (ELCON CL 65 dryer, at ca. $33^{\circ} \mathrm{C}$ ), and then the pollen was rinsed from anthers once with pure ether $(1-2 \mathrm{ml})$ and then 4-6 times with $70 \%$ ethanol (2-8 ml). Four replications $\mathrm{n}=100$ anthers were collected every year. The mass of produced pollen was calculated for 100 anthers, and per shrub. Pollen viability was tested in standard acetocarmine slides. The secretion of nectar was checked, according to $\mathrm{J} \mathrm{a} \mathrm{b} \mathrm{ł} \mathrm{o} \mathrm{ń} \mathrm{s} \mathrm{ki} \mathrm{[20]} \mathrm{but} \mathrm{not} \mathrm{quantified} \mathrm{in} \mathrm{this} \mathrm{study.}$

Insect activity. Simultaneously to the blooming observations the pattern and intensity of insects visits were noted for three consecutive days at one-hour intervals, at the time of the most intensive forage activ- ity of pollinators, between 8.00 and $20.00 \mathrm{~h}$ (GMT + $2.00 \mathrm{~h}$ ). The daily pattern of insect visitation for the full flowering period was recorded in 2006 and 2009 for the individual shrubs.

Data analysis. Data are presented as means with SD. The standard analysis of variance was applied [21]. Post hoc comparison of means for the number of flowers, the pollen production and viability was tested by the Duncan t-test. The flower life-span and the corolla length were compared using the independent samples ttest. The level of statistical significance for all analyses was at a $=0.05$. All analyses were performed using Statistica 6.0 (StatSoft Poland, Krakow).

\section{RESULTS}

The detailed dates of seasonal phenology are shown in Table 1. During the study period, Syringa oblata var. dilatata started to bloom insensibly earlier (2006), simultaneously (2009) or insensibly latter (2013) compared to S. meyeri 'Palibin'. Generally, the flowering began in mid May and lasted till mid June. The duration of flowering varied from 21-24 days ( $S y$ ringa oblata var. dilatata) and from 22-29 days (S. meyeri 'Palibin'). The flowers opening noted was slightly more intense for the S. meyeri 'Palibin' with approx. of $60 \%$ of daily instalment of flowers have been peaking at 8.00 (Fig. 1). Most flowers of Syringa oblata var. dilatat $a$ were opened between 8.00-9.00 (GMT $+2 \mathrm{~h})$. In the following hours (10.00-18.00), ca. $1-10 \%$ of flowers were opened in one hour intervals.

The species effect for the flower longevity was found $(\mathrm{t}=0.356, \mathrm{df}=37, \mathrm{p}<0.025)$. Irrespective of the weather conditions, a longer life-span was characteristic for a single flower of $S$. oblata var. dilatata (mean $=5.9$ $\pm 2.2 \mathrm{SD}$ ) than a single flower of $S$. meyeri 'Palibin' $($ mean $=4.5 \pm 1.7 \mathrm{SD})$. The duration of floral longevity was also dependant on the air temperature $(t=0.156$, $\mathrm{df}$ $=37, \mathrm{p}<0.041$ ).

The considerable elongation of the corolla tube was observed between the swollen bud phase and the pollen presentation phase of the flower development. Both species studied had the corolla tube 2-fold deeper during the pollen shedding phase compared to the swollen bud phase (mean $=14.9 \mathrm{~mm} \pm 3.2 \mathrm{SD}$ vs. $7.8 \mathrm{~mm} \pm$ 2.8) $(\mathrm{t}=0.456, \mathrm{df}=66, \mathrm{p}<0.032)$.

The lilac flowers are arranged in compound panicle. The single inflorescence of $S$. meyeri 'Palibin' grouped more flowers (mean $=138.7)$ than $S$. oblata var. dilatata $($ mean $=115.8)$ and the difference was statistically significant $\left(\mathrm{F}_{1,68}=29.22, \mathrm{p}=0.023\right)$.

New flowers were constantly developed on each individual inflorescences and shrubs. The number of flowers per shrub was species related (Table 1). Also year-to-year variations were found for both species. The shrubs of $S$. oblata var. dilatata, developing 49,400 
flowers per shrub, flowered 8-fold more abundant than $S$. meyeri 'Palibin'. Both species developed the lowest number of flowers in the year 2006.

The flowers of both species are bisexual. The calyx is four-lobed, and the four-lobed corolla is gamopetalous with a cylindrical basal tube. The centrally positioned gynoecium consists of one pistil with two-lobed stigmas. Two stamens are fused with the corolla at the base. The release of pollen began approx. 3-4 hours after anthesis. Most anthers dehisced between 12.00 and $15.00($ GMT $+2 \mathrm{~h})$. Usually pollen was released simultaneously in 4 anthers per single flower. At a mean air temperature $25-30^{\circ} \mathrm{C}$ the pollen release was very intensive and entire quantity of pollen per anther was released in 2-3 hours. During temperature drop at a mean $15-20^{\circ} \mathrm{C}$ the process was slower and lasted 5-8 hours.

The statistical analysis of the mass of pollen produced in anthers revealed significant year effect, for $S$. oblata var. dilatata $\left(\mathrm{F}_{2,11}=6.59, \mathrm{p}=0.0321\right)$ and for $S$. meyeri 'Palibin' $\left(\mathrm{F}_{2,11}=12.14, \mathrm{p}=0.016\right)$. Both species reacted similarly for the external environmental factors and produced the lowest amounts of pollen in the year 2013, which was approx. twice lower compared to values obtained in the other years. Also the lowest pollen viability was noted in 2013. No species effect was found for the size of anthers, measured as the dry mass of anthers $\left(\mathrm{F}_{1,17}=3.29, \mathrm{p}=0.321\right)$, for the mass of pollen produced in anthers $\left(\mathrm{F}_{1,17}=1.98, \mathrm{p}=0.421\right)$ and for the pollen viability $\left(\mathrm{F}_{1,16}=2.23, \mathrm{p}=0.081\right)$.

The mass of pollen produced per inflorescence depended on both the number of flowers developed and the efficiency of archesporial tissues. The average pollen output was from $9.6-29.1 \mathrm{mg}$ per inflorescence of $S$. oblata var. dilatata, and from 9.6-28.5 mg per inflorescence of S. meyeri 'Palibin'. The mass of pollen produced per individual shrub substantially related to the abundance of blooming. The average estimated pollen yield, in the full flowering phase, amounted $0.9 \mathrm{~kg}$ for $S$. meyeri 'Palibin', and $8.1 \mathrm{~kg}$ for S. oblata var. dilatata per individual shrub.

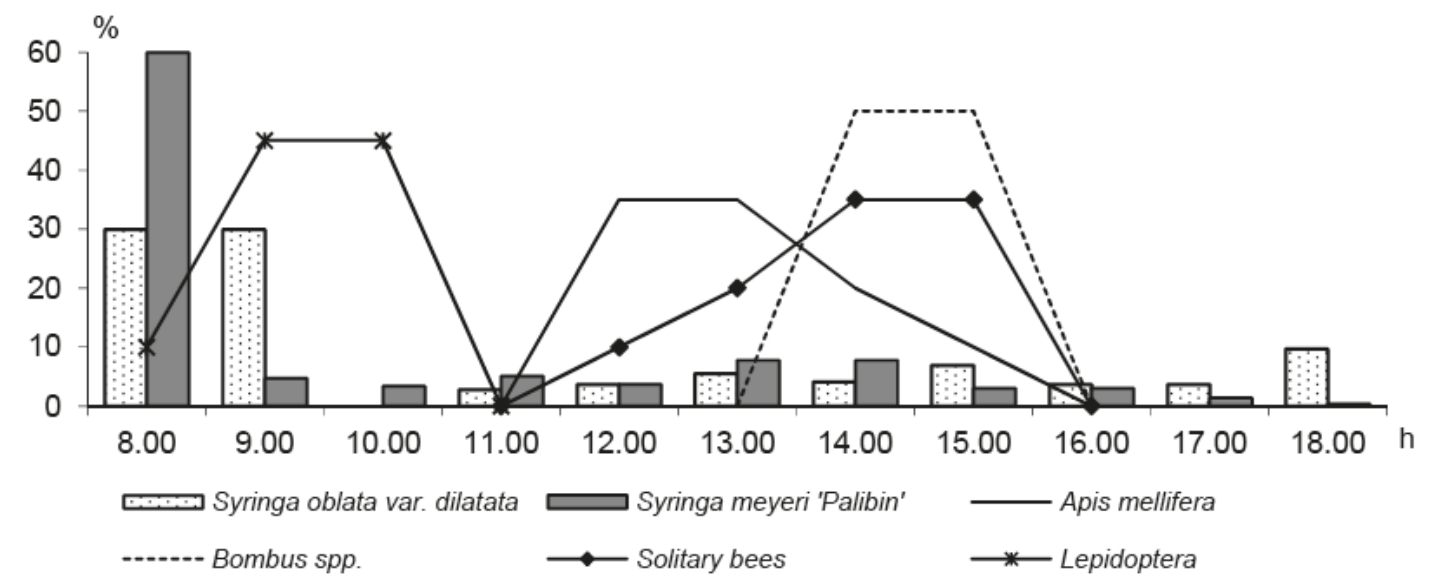

Fig. 1. Diurnal pattern of flowering of two Syringa species expressed as the number of flowers opened in one hour intervals in relation of the total opened during the day and the diurnal activity of insect visitors observed in SE Poland (means calculated from 2006 and 2009).

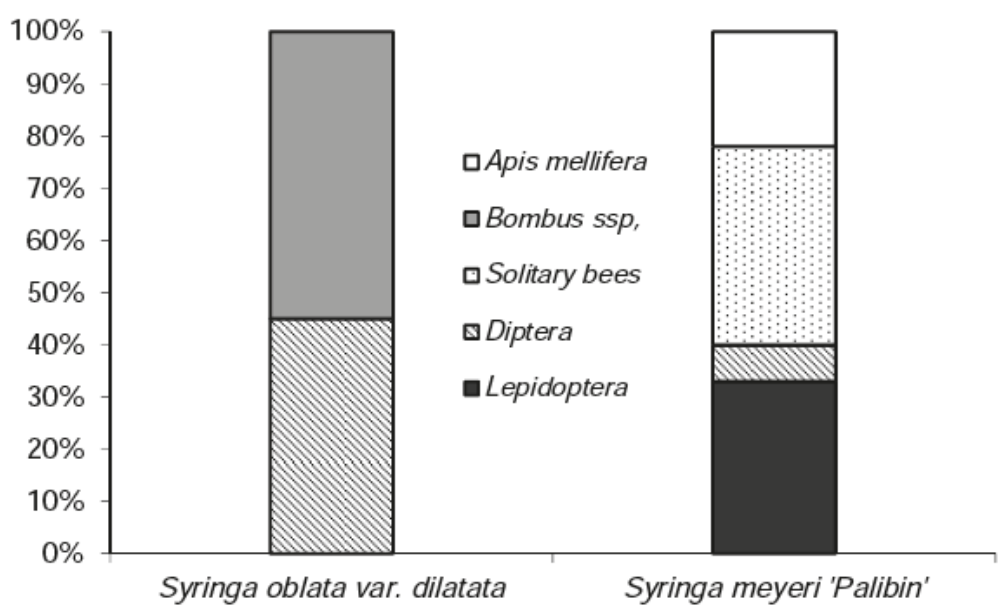

Fig. 2. The participation of insect visitors on the flowers of two Syringa species observed in SE Poland (means calculated from 2006 and 2009). 
Table 1

Flowering period, features of blooming and abundance of flowering in two Syringa species in the years 2006, 2009 and 2013, observed in SE Poland

\begin{tabular}{|c|c|c|c|c|c|c|c|c|c|c|}
\hline \multirow{3}{*}{ Species } & \multirow{3}{*}{ Year } & \multirow{3}{*}{$\begin{array}{c}\text { Flowering } \\
\text { period }\end{array}$} & \multirow{2}{*}{\multicolumn{2}{|c|}{$\begin{array}{c}\begin{array}{c}\text { Flower life-span } \\
\text { (days) }\end{array} \\
\text { air temperature }\end{array}$}} & \multirow{2}{*}{\multicolumn{2}{|c|}{$\begin{array}{c}\begin{array}{c}\text { Length of corolla } \\
(\mathrm{mm})\end{array} \\
\text { phase }\end{array}$}} & \multirow{2}{*}{\multicolumn{2}{|c|}{$\begin{array}{l}\text { Number of flowers } \\
\text { per inflorescence }\end{array}$}} & \multirow{2}{*}{\multicolumn{2}{|c|}{$\begin{array}{c}\text { Number of flowers } \\
\text { per shrub (thous.) }\end{array}$}} \\
\hline & & & & & & & & & & \\
\hline & & & $10-15^{\circ} \mathrm{C}$ & $20-25^{\circ} \mathrm{C}$ & bud & pollen shead & $\min -\max$ & mean & $\min -\max$ & mean \\
\hline \multirow{4}{*}{$\begin{array}{l}\text { Syringa oblata } \\
\text { var. dilatata }\end{array}$} & 2006 & 13.05-2.06 & 5.1 & 4.2 & 7.9 & 15.3 & $61-167$ & $110.6_{a}$ & $0.5-169.0$ & 30.8 \\
\hline & 2009 & $9.05-1.06$ & 7.2 & 5.4 & 8.3 & 16.1 & $54-214$ & $142.6_{b}$ & $0.8-182.5$ & 62.5 \\
\hline & 2013 & $18.05-10.06$ & 8.1 & 6.1 & 6.4 & 13.1 & $47-121$ & $94.3_{\mathrm{a}}$ & $0.7-153.8$ & 54.9 \\
\hline & mean & & 6.8 & 5.2 & 7.5 & 14.8 & & $115.8_{\mathrm{A}}$ & & 49.4 \\
\hline \multirow{4}{*}{$\begin{array}{l}\text { Syringa meyeri } \\
\text {,Palibin' }\end{array}$} & 2006 & $22.05-12.06$ & 4.2 & 2.4 & 8.0 & 15.1 & $126-180$ & $150.6_{\mathrm{b}}$ & $1.1-10.8$ & 4.2 \\
\hline & 2009 & 12.05-9.06 & 6.4 & 4.1 & 9.1 & 15.8 & $134-199$ & $163.6_{\mathrm{b}}$ & $1.8-13.5$ & 7.4 \\
\hline & 2013 & $15.05-12.06$ & 7.6 & 4.1 & 7.1 & 14.2 & $102-136$ & $101.8_{\mathrm{a}}$ & $1.0-12.5$ & 6.4 \\
\hline & mean & & 6.1 & 3.5 & 8.1 & 15.0 & & $138.7_{\mathrm{B}}$ & & 6.0 \\
\hline Mean & & & 6.5 & 4.4 & 7.8 & 14.9 & & 127.3 & & 27.7 \\
\hline
\end{tabular}

Means in columns with the same letters are not significantly different at $\alpha=0.05$ (Duncan t-test)

Table 2

The fresh and dry mass of anthers, the mass of produced pollen, total pollen yield and pollen viability in two Syringa species in the years 2006, 2009 and 2013, observed in SE Poland

\begin{tabular}{|c|c|c|c|c|c|c|c|}
\hline \multirow{3}{*}{ Species } & \multirow{3}{*}{ Year } & \multirow{3}{*}{$\begin{array}{l}\text { Dry mass of } \\
100 \text { anthers } \\
(\mathrm{mg})\end{array}$} & \multicolumn{4}{|c|}{ Mass of pollen per } & \multirow{3}{*}{$\begin{array}{c}\text { Viability } \\
(\%)\end{array}$} \\
\hline & & & \multicolumn{2}{|c|}{100 anthers (mg) } & \multirow{2}{*}{$\begin{array}{l}\text { inflorescence } \\
\text { (mg) }\end{array}$} & \multirow{2}{*}{$\begin{array}{c}\text { shrub } \\
(\mathrm{kg})\end{array}$} & \\
\hline & & & $\min -\max$ & mean & & & \\
\hline \multirow{4}{*}{$\begin{array}{l}\text { Syringa oblata } \\
\text { var. dilatata }\end{array}$} & 2006 & $29.2_{\mathrm{b}}$ & $7.1-11.5$ & $9.4_{b}$ & 20.8 & 5.8 & $89.4_{b}$ \\
\hline & 2009 & $32.1_{\mathrm{b}}$ & $9.2-12.3$ & $10.2_{\mathrm{b}}$ & 29.1 & 12.8 & $82.3_{\mathrm{b}}$ \\
\hline & 2013 & $19.8_{a}$ & $4.8-7.7$ & $5.1_{\mathrm{a}}$ & 9.6 & 5.6 & $62.5_{a}$ \\
\hline & mean & $27.0_{\mathrm{A}}$ & & $8.2_{\mathrm{A}}$ & 19.8 & 8.1 & $78.1_{\mathrm{A}}$ \\
\hline \multirow{4}{*}{$\begin{array}{l}\text { Syringa meyeri } \\
\text {,Palibin’ }\end{array}$} & 2006 & $31.4_{b}$ & $7.8-11.2$ & $9.0_{\mathrm{b}}$ & 27.1 & 0.8 & $87.3_{\mathrm{b}}$ \\
\hline & 2009 & $26.9_{\mathrm{ab}}$ & $8.2-12.8$ & $8.7_{\mathrm{b}}$ & 28.5 & 1.3 & $85.4_{b}$ \\
\hline & 2013 & $23.4 \mathrm{a}$ & $4.1-6.9$ & $4.7 \mathrm{a}$ & 9.6 & 0.6 & $52.4_{a}$ \\
\hline & mean & $27.2_{\mathrm{A}}$ & & $7.5_{\mathrm{A}}$ & 21.7 & 0.9 & $75.0_{\mathrm{A}}$ \\
\hline Mean & & 27.1 & & 7.9 & 20.8 & 4.5 & 76.6 \\
\hline
\end{tabular}

Means in columns with the same letters are not significantly different at $\alpha=0.05$ (Duncan t-test)

\section{DISCUSSION}

In the environmental conditions of south-eastern Poland Syringa oblata var. dilatata and S. meyeri 'Palibin' bloomed from mid May till mid June. This is about one-three weeks later then an average blooming period registered for western Poland [6]. The timing and duration of a species' flowering may be influenced by biotic and/or abiotic factors [22], and they indicate the discrepancies in flowering between species, seasons and sites.

The diurnal pattern of blooming was similar for both species. Most flowers were opened in the morning hours between $(8.00-9.00 \mathrm{~h})$, that indicates their rise in the early morning or even at night. There are no adequate data about diurnal rhythm of Syringa spp. blooming found in the literature. Some authors insist on genetic determination or even phylogenetic constraints of the trait [17,22]. However, the impact of environmental factors on the diurnal pattern of blooming was found for different species [18,23,24]. In our study no substantial difference for the pattern of diurnal sequence of flower opening in Syringa spp. was revealed between subsequent days or growing seasons, suggesting a very high degree of genetic influence.

The flowers of Syringa species studied conforms to the general pattern of the family Oleaceae 
[1]. The corolla forms a deep tube $(10-17 \mathrm{~mm})$. The characteristic was described by Li piński [7], who pointed out that the feature may limit the access of insect visitors to floral reward. Flowers of the studied $S y$ ringa species offered both nectar and pollen, although we quantified only pollen reward in this study. Different groups of insect visitors were observed on flowers, including Apoidea bees, although their density was extremely low (only 1-2 visitors per hour). We observed lepidopterans foraging on flowers of both Syringa species early in the morning only. Szafer and $\mathrm{Woj}$ t u si a k ow a [25] consider the lilacs among typical lepidopterans pollinated species. The adult butterflies were able, using their long proboscis, to reach the nectar hidden at the base of deep corolla tube of lilacs observed. The short-tongue visitors occasionally foraged for nectar, and only in mid-day hours. The flowering of studied lilacs overlap with many other shrubs and trees present in nearby surrounding. Some of them (e.g. Cotoneastr spp., Deutzia species) are regarded as very good flow species [10], and in the selection between rewarding and nectar-less plants visiting insects could avoid less attractive lilacs.

The studied species produced numerous flowers per inflorescence (94.3-163.6) and the number differed between species and among growing seasons. Syringa species and cultivars are known of producing terminal panicles which differ in the number of flowers [6]. The number of flowers developed per inflorescence is considered a genetic feature [22] and also is highly dependant on weather factors [17]. Studies of trees grown in temperate climate showed that differentiation of flower organs continues through two growing seasons [26]. In Syringa vulgaris the flower primordia differentiation and flower organ development starts in midsummer and lasts until autumn and is completed in six to eight weeks during the spring following the year of initiation [27]. In our study both Syringa species developed the smallest number of flowers in 2013, when flowering followed the summer and autumn of 2012, with the lack of precipitation (August/September c.a. 180-240\% lower than in long-term). This indicates the drought as limiting factor for the bud formation in examined Syringa species and consequently for the abundance of blooming.

In the flowers of studied Syringa species most anthers dehisced in mid-day hours. This is a trait common in many plant species [19], and is derivative to the mechanisms of anther dehiscence that is related to daily cycles of declining the relative humidity and rising the air temperature that enhance evaporative water loss from the locular fluid and accelerate the structural changes in plant tissue that lead to dehiscence $[28,29]$.

According to our knowledge, the study are the first on the pollen production of Syringa species. The mass of pollen offered by the anthers of Syringa oblata var. dilatata and S. meyeri 'Palibin' was similar but the value differed among years of study. J ę d r z e j u k and Szlachetka [27] revealed the differentiation of pollen mother cells in anthers during bud breaking after winter dormancy in Syringa vulgaris. The air temperature drops during bud cracking in the studied Syringa species were noted in the year 2013, and resulted in the decrease in both the mass of pollen produced in anthers and the pollen viability. The noted dependence indicates that the microsporogenesis and the pollen production in the studied Syringa species is sensitive for external factors, i.e low temperatures.

A constant number of 2 stamens in the flowers of Syringa species entail the pollen yield is derivative mainly to the number of developed flowers. Therefore significant differences were noted between pollen yield per shrub $(0.9-8.1 \mathrm{~kg} / \mathrm{ha})$. The impact of the abundance of blooming for the total pollen yield was underlined by different authors $[23,30]$.

The average mass of pollen produced in the anthers of studied lilacs was 7.5-8.2 mg per 100 anthers. The value is similar to obtained from anthers in Rosa multiflora (9.5 mg per 100 anthers), in Chaenomeles sp. (3.6-11.5 mg) or in Aesculus hypocastanum (6.5$10.6 \mathrm{mg}$ per 100 anthers), but not in flowers [30-32]. The dependence is clear comparing the androecium (2-stamens in Syringa vs. multi-stamens in Rosa or vs. 5-9-stamens in Aesculus).

In conclusion, the Syringa oblata var. dilatata and S. meyeri 'Palibin' due to their attractive flowering period, and the abundance of blooming are suitable for different ornamental designs in urban areas. Unfortunately, despite the entomophilous flower features, due to very deep corolla tube, the insect visitors used the floral reward offered sporadically.

\section{Acknowledgements}

Research was supported financially by the Ministry of Science and Higher Education of Poland as a part of statutory activities of the Department of Botany, University of Life Sciences in Lublin.

\section{Authors' contributions}

The following declarations about authors' contributions to the research have been made: designed the experiments: $\mathrm{BD}$; performed the experiments: MSA; analyzed the experimental data: $\mathrm{BD}$; wrote the paper: BD, MSA

\section{REFERENCES}

1. Heyw ood VH. Flowering plants of the world. London: Croom Helm; 1985. 
2. Wa in es JG. Lilacs blooming out of season. Lilacs. 2005; 34(2): 49-51.

3. Li ZG, Lee MR, Shen DL. Analysis of volatile compounds emitted from fresh Syringa oblata flowers in different florescence by headspace solid-phase microextraction-gas chromatography-mass spectrometry. Anal Chim Acta. 2006; 576(1): 43-49. http://dx.doi.org/10.1016/j.aca. 2006.01.074

4. Seneta W, Dolatowski J. Dendrologia. Warsaw: Polish Scientific Publishers PWN. 2008.

5. Bodnarczuk LI, Solomacha TD, Illiasz AM, Solomacha WA. Atlas medonosnich roslin Ukrainy. Kijev: Urożaj. 1993.

6. B u ga ł a W. Drzewa i krzewy. Warsaw: Państwowe Wydawnictwo Rolnicze i Leśne; 2000.

7. Lipiński M. Pożytki pszczele. Zapylanie i miododajność roślin. 4th ed. Warsaw: Państwowe Wydawnictwo Rolnicze i Leśne. 2010.

8. Glu chov M. Važniejszyje miedonosnyje rastienija i sposoby ich razviedienija. Moscow: Gosudar Izdat Selskochoz Lit. 1950 .

9. Jabłoński B, Kołtowski Z. Nektarowanie i wydajność miodowa roślin miododajnych w warunkach Polski. Część XI. [Nectar secretion and honey potential of melliferous plants in environmental conditions of Poland]. Part XI. Pszczeln Zesz Nauk. 2000; 44: 205-211.

10. Kołtowski Z. Wielki atlas roślin miododajnych. Warsaw: Publishing Enterprise Rzeczpospolita. 2006.

11. Wróblewska A, Warakomska Z, Koter M. Pollen analysis of bee products from the north-eastern Poland. J Api Sci. 2006; 50(1): 71-83.

12. Wróblewska A, Warakomska Z. Pollen analysis of honey from Poland's Lubelszczyzna Regions. J Api Sci. 2009; 53(2): 57-67.

13. Konarska A. Characteristics of the surface of the epidermis in floral nectaries and the receptacle of mountain ash (Sorbus aucuparia L.). Acta Agrobot. 2007; 60(2): 23. http://dx.doi.org/10.5586/aa.2007.026

14. Weryszko-Chmielewska E, Bożek M. Structure of trichomatous nectaries in flowers of Lonicera kamtschatica (Sevast.) Pojark. Acta Agrobot. 2008; 61(1): 13. http://dx.doi.org/10.5586/aa.2008.002

15. Weryszko-Chmielewska E, Chwil M, Wróbe $1 \mathrm{M}$. The position and structure of the nectary in spring heath (Erica carnea L.) flowers. Acta Agrobot. 2009; 62(2): 13. http://dx.doi.org/10.5586/aa.2009.022

16. Olszewska E. Ogrody. Projekty. Projekty polskich architektów. Muza. 2009.

17. Jabłoński B, Szkla nowska K. Wpływ niektórych czynników pogody na kwitnienie, nektarowanie, pylenie i oblot przez owady zapylające entomofilnych roślin uprawnych. LTN. 1997.

18. Den is ow B. Factors determining the diurnal dynamics of blooming of chosen plant species. Acta Agrobot. 2009; 62(1): 83. http://dx.doi.org/10.5586/aa.2009.010

19. D e n is ow B. Pollen production of selected ruderal plant species in the Lublin area. Lublin: University of Life Sciences in Lublin Press. 2011.
20. Jabłoński B. Notes on the method to investigate nectar secretion rate in flowers. J Api Sci. 2002; 46(2): 117-124.

21. Stanis z A. Przystępny kurs statystyki z zastosowaniem Statistica na przykładach z medycyny. Cracow: Statsoft Polska; 1996.

22. Kochmer JP, Handel SN. Constraints and competition in the evolution of flowering phenology. Ecol Mono. 1986; 56(4): 303. http://dx.doi.org/10.2307/1942549

23. De nis ow B, B ożek M. Blooming and pollen production of two Lamium L. species. J Api Sci. 2008; 52(1): 21-30.

24. Weryszko-Chmielewska E, Dmitruk M. Characteristics of blooming, floral nectaries and nectar of Malus sargentii Rehd. Acta Agrobot. 2009; 62(1): 17-25.

25. Szafer W, Wojtusiakowa H. Kwiaty i zwierzęta. Zarys ekologii kwiatów. Warsaw: Polish Scientific Publishers PWN. 1969.

26. Hu a n $\mathrm{H}$. Flower bud development in apple trees as related to node formation. J Fruit Ornam Plant Res. 1996; 4: 253-261.

27. Jędrzejuk A, Szlachetka W. Development of flower organs in common lilac (Syringa vulgaris L.) cv. Mme Florent Stepman. Acta Biol Cracov Ser Bot. 2005; 47(2): 41-52.

28. Keijzer C J. The processes of anther dehiscence and pollen dispersal. New Phytol. 1987; 105(3): 487-498. http://dx. doi.org/10.1111/j.1469-8137.1987.tb00886.x

29. P a c in i E. From anther and pollen ripening to pollen presentation. Pl Syst Evol. 2000; 222(1-4): 19-43. http://dx. doi.org/10.1007/BF00984094

30. Szklanowska K, Strzałkowska M. Blooming biology and pollen exposure of horse chestnut trees (Aesculus L.). Ann UMCS Sec E. 2000; 8: 107-116.

31. Den is ow B. The blooming and melliferous value of tristilous flowers of Japanese quince (Chaenomeles japonica Lindl.). J Api Sci. 2002; 46(2): 15-22.

32. Szklanowska K, Strzałkowska M. Blooming biology and flow value of Rosa multiflora Thunb. shrubs. Ann UMCS Sec E. 2001; 9: 33-34.

\section{Charakterystyka kwitnienia i pyłek w kwiatach dwóch gatunków z rodzaju Syringa (f. Oleaceaeae)}

\section{Streszczenie}

W latach 2006, 2009, 2013, na terenie Lublina $\left(51^{\circ} 16^{\prime} \mathrm{N}, 22^{\circ} 30^{\prime} \mathrm{E}\right)$ badano fenologię, dzienny rytm kwitnienia, obfitość kwitnienia, produkcję pyłku krzewów Syringa oblata var. dilatata oraz S. meyeri 'Palibin'. Monitorowano również zainteresowanie owadów pożytkiem. Badane krzewy kwitną na przełomie maja i czerwca. Kwiaty charakteryzują się wczesnym dobowym rytmem rozkwitania (ok. 60\% dobowej porcji kwiatów rozkwita do 9.00). Rurka korony w fazie prezentacji pyłku jest przeciętnie 2-krotnie dłuższa niż w fazie nabrzmiałego pąka. Wielkość pylników, masa 
produkowanego pyłku oraz żywotność pyłku nie różniły się istotnie pomiędzy gatunkami. Stała liczba pręcików (2) w kwiecie powoduje, że wydajność pyłkowa krzewów zależy głównie od liczby wytworzonych kwiatów. Stąd notowano znaczne różnice w produktywności pyłku, średnio $0.9 \mathrm{~kg} / \mathrm{ha} \mathrm{z}$ krzewów $S$. meyeri 'Palibin', oraz $8.1 \mathrm{~kg} / \mathrm{ha} \mathrm{z}$ krzewów $S$. oblata var. dilatata.
Krzewy Syringa oblata var. dilatata i S. meyeri 'Palibin', ze względu na atrakcyjny termin kwitnienia oraz obfite kwitnienie nadają się do wykorzystania w założeniach miejskich. Niestety, kwiaty pomimo typowych cech entomofilnych są sporadycznie odwiedzane prze owady.

Handling Editor: Elżbieta Weryszko-Chmielewska

This is an Open Access digital version of the article distributed under the terms of the Creative Commons Attribution 3.0 License (creativecommons.org/licenses/by/3.0/), which permits redistribution, commercial and non-commercial, provided that the article is properly cited.

CThe Author(s) 2013 Published by Polish Botanical Society 